\title{
Perspektif Islam tentang Hutang Luar Negeri dan Hutang Luar Negeri Negara-negara Islam
}

\author{
MB Hendrie Anto
}

Foreign debt, for quite long time has been considered as one of financial sources for the process of development in various developing countries, including Islamic countries. Some of Islamic countries stand on big outstanding debts that significantly burden them, whereas other countries, conversely, possess huge financial sources. This article tries to analyze the foreign debt from the Islamic perspective, also tries to look at the factual data on the foreign debt among Islamic countries. The article also suggests the solutions needed to overcome the problem pertaining with foreign debt. There is a complex combination between internal and external factors beyond this problem. The improvement of the economic performance of the country and also the collaboration among Islamic countries are the basic element to solve the problem.

\section{Pendahuluan}

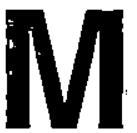

asalah hutang luar negeri sebagai sumber pembiayaan pembangunan (deficit budged) telah menjadi bahan perdebatan klasik, baik dalam tataran teoritis maupun praktis. Dalam pemikiran Rostow, posisi hutang luar negeri dianggap sebagai the missing link dalam mata rantai pembangunan ekonomi. Dalam dunia praktis, hutang luar negeri merupakan vicious cyrcle dalam pembangunan, khususnya negaranegara berkembang. Tercatat beberapa kali dunia mengalami debt crisis yang hebat, misalnya tahun 1930-an, 1980an dan 1990an saat ini. Hingga kini, penyelesaian hutang luar negeri masih merupakan problematika yang kompleks dan rumit untuk dipecahkan.

Dalam prespektif Islam masalah hutang luar negeri ini menjadi penting setidaknya karena dua hal, yaitu: (1) Islam memiliki pandangan yang eksklusif tentang hutang luar negeri, (2) Banyak negara Islam yang 
terlilit oleh hutang luar negeri yang cukup besar.' Secara normatif , Islam kaya akan khasanah pemikiran bagi pembangunan ekonomi. Sementara itu, secara faktual banyak sumber daya ekonomi yang dimiliki oleh negara-negara Islam potensial untuk menyelesaikan permasalahan hutang ini, bahkan mempercepat akselerasi pembangunan ekonomi. Namun, hingga saat ini kerjasama di antara negara-negara Islam, terutama antara negara kaya dan miskin, untuk menyelesaikan hutang luar negerinya serta membangun perekonomian masih lemah. Beberapa kerjasama yang ada masih bersifat lokal, berskala kecil, dan lebih dilatar belakangi oleh motif etnis, politik atau keagamaan (dalam arti sempit).

Tulisan ini akan membahas prespektif Islam terhadap masalah hutang luar negeri dalam pembiayaan pembangunan, diskripsi realitas hutang luar negeri - negara-negara Islam, serta bagaimana alternatif pemecahan problema kompleks ini?

\section{Hutang Luar Negeri dalam Prespektif Ekonomi}

1. Hutang Luar Negeri dalam Teori Konvensional

Dalam penjelasan teori-teori konvensional; setidaknya terdapat dua teori yang dapat menjelaskan tentang urgensi hutang luar negeri bagi pembiayaan pembangunan. Teori pertama mengatakan bahwa hutang luar negeri, seperti halnya investasi asing, diperlukan untuk menutup saving gap dalam terminologi kelompok Neo Klasik. ${ }^{2}$ Jadi dalam hal ini hutang luar negeri dibutuhkan karena domestic saving tidak mencukupi untuk pembiayaan pembangunan. Sebenarnya untuk menutup saving gap dapat dilakukan dalam dua bentuk, yaitu Debt Creating Flow dan Non Debt Creating Flow. DCF dapat berupa hutang bilateral maupun multilateral, sedangkan NDCF berupa penanaman dan penyertaan modal seperti Foreign Direct Investment (FDI), short term capital dan long term capital. Teori yang kedua menjelaskan fenomena hutang luar negeri dari sisi neraca pembayaran, di mana merupakan salah satu account pada neraca modal, yang bersifat mengakomodasikan kepentingan neraca berjalan yang bersifat otonom. Jadi bila neraca berjalan mengalami defisit, maka akan dikompensasikan dengan hutang luar negeri dalam neraca moda!. Dalam konteks ini hutang luar negeri dapat berfungsi sebagai gap filling, yaitu mengisi gap akibat defisit neraca berjalan. ${ }^{3}$

Hutang luar negeri merupakan salah satu sumber pembiayaan pembangunan yang sangat signifikan bagi negara berkembang. Namun demikian, hasil studi tentang dampak hutang terhadap

'Yang dimaksud Negara Islam dalam makalah ini adalah negara yang tergabung dalam Organisasi Konferensi Islam (Organisation of Islamic Conference), di mana kriteria yang digunakan lebih pada masalah demografi.

${ }^{2}$ Todaro, Michel P. (1994), Economic Development, 5th Edition, New York, Longman Publishing

'Lihat misalnya dalam Ingam, James C. (1986), Intemational Economics, New York, John Wiley \& Sons. Dana-dana utang luar negeri yang diberikan oleh IMF misalnya, banyak yang bertujuan untuk mengisi gap ini, disamping untuk mendorong tabungan nasional dan pembentukan modal tetap. Lihat Haque, $M$ Badhul, and Charles Waternberg (1992) "Direct Effect of Debt Overhang and IMF Program", Review of Financial Economics, Spring sebagaimana dikutip oleh Toni Prasetiantono. (1996), "Utang Luar Negeri dan Defisit Transaksi Berjalan", Kelola, Yogyakarta, Magister Manajemen Universitas Gadjah Mada, No $12 N$. 
pembangunan ekonomi menunjukkan hasil yang berbeda-beda. Beberapa ilmuwan memperoleh kesimpulan bahwa hutang luar negeri justru telah menimbulkan pelambatan pertumbuhan ekonomi bagi negara-negara pengutang besar, sementara beberapa studi lain menyimpulkan sebaliknya-yaitu hutang luar negeri menjadi salah satu faktor yang secara signifikan mendorong pertumbuhan ekonomi negaranegara pengutang. ${ }^{4}$

Banyak negara sedang berkembang (NSB) yang kini telah masuk dalam perangkap hutang (Debt Trap), dan akhirnya hanyut dalam lingkaran ketergantungan hutang (debt overhang hypothesis). ${ }^{5}$ Dalam konteks argumentasi ini, patut dipertanyakan kembali relevansi dan urgensi hutang luar negeri dalam pembiayaan pembangunan negara-negara berkembang.

\section{Hutang Luar Negeri Dalam Prespektif Islam}

Secara umum terdapat dua pandangan tentang tentang hutang luar negeri sebagai alternatif menutup defisit anggaran negara. Pandangàn pertama menganggap bahwa external financing merupakan hal yang diperbolehkan dalam Islam, meskipun bentuk dan mekanismenya memerlukan modifikasi. Pandangan yang kedua menganggap bahwa negara Islam tidak selayaknya mencari hutang luar negeri sebagai penutup saving gapnya. ${ }^{6}$

Pandangan pertama ini pada dasarnya membolehkan adanya budgèd deficit yang ditutup dengan external financing, sepanjang bentuk dan mekanismenya disesuaikan dengan syariah. Pandangan dilatar belakangi oleh konsep dan fakta historis bahwa kerjasama dengan pihak lain dalam suatu usaha diperbolehkan, bahkan dianjurkan. Bentuk-bentuk kerjasama yang diperkenankan dalam syariah, seperti mudharabah, musyarakah, murabahah, dll, dapat dikembangkan sebagai bentuk external financing dalam anggaran negara. Bentuk-bentuk ini pada prinsipnya lebih bersifat flow creating equity daripada flow creating debt, di mana mulai banyak diimplementasikan oleh lembaga-lembaga keuangan internasional. Islamic Development Bank (IDB) telah banyak membiayai proyek di negara-negara islam dengan skema ini. Dibandingkan dengan hutang, penyertaan modal dipandang lebih konstruktif, proporsional dan fair dalam pembiayaan, karena terdapat pembagian perolehan dan resiko (loss-profit sharing).

Pandangan kedua melarang negara Islam untuk menutup budged deficit dengan hutang luar negeri. Pandangan ini sebenarnya lebih dikarenakan pertimbangan faktual dan preventif, di mana keterlibatan negaranegara Isiam dalam hutang luar negeri pasti akan berinteraksi dengan sistem bunga. Dalam perspektif Islam, bunga (apapun motifnya-produksi-konsumsi, berapapun

${ }^{4}$ Beberapa penelitian yang mendukung kesimpulan yang pertama misalnya Kenen (1990), Sachcs (1990) dan Dorn Busch (1988), sementara yang mendukung kesimpulan kedua antara lain Cohen (1993), Bulow dan Rogof (1990). Sementara itu Chowdurry (1997) menyimpulkan bahwa dampak ini bervariasi dari satu negara dengan negara lain. Lihat Chowdurry, Khorshed dan Amnon Levy. (1997), "Utang Eksternal dan Implikasinya terhadap Pertumbuhan Ekonomi", Jumal Ekonomi Pembangunan, Yogyakarta, Fakultas Ekonomi UII, Volume 2 Nomor 2 hal 337.

${ }^{5}$ Kaminsky, Graciela L dan Alfredo Preiera (1996), "The Debt Crisis : Lessons of the 1980s for the 1990s", Joumal of Development Economics, $\mathrm{Vol} 50$

GMannan, Abdul (1992), Teori dan Praktek Ekonomi Islam, Yogyakarta, PT Dana Bhakti Wakaf, hal 237-238. 
besarnya-tinggi/berlipat-lipat/atau rendah) dipandang sebagai riba, dan karenanya dilarang oleh agama dengan tegas. ${ }^{7}$ Pada akhirnya, hal ini akan menjerumuskan dalam berbagai bentuk transaksi riba yang dilarang oleh agama. Dengan demikian maka sebaiknya negara Islam tidak memiliki hutang luar negeri. Dalam fakta, bunga hutang luar negeri juga telah menjadi beban yang berat bagi negara-negara debitur.

Sejarah perekonomian masa Rasulullah saw menunjukkan bahwa defisit anggaran hanya pernah terjadi pada saat Penaklukan Mekkah (Fathul Makkah), tetapi segera dilunasi pada periode Perang Hunain. Kebanyakan anggaran negara waktu itu seimbang atau surplus, sebagaimana kemudian banyak diikuti oleh khulafah ar rasyidin pada masa berikutnya. Pertimbangan utama keseimbangan anggaran saat itu adalah prinsip kesederhanaan dan kemampuan sebagaimana dalam ajaran Islam.

\section{Hutang Luar Negeri Negara-negara Islam}

\section{Struktur Hutang Luar Negeri}

Dalam beberapa dekade teräkhir ini perekonomian dunia didera oleh krisis finansial yang diakibatkan oleh hutang luar negeri negara-negara sedang berkembang (NSB). Krisis hutang pertama kali terjadi tahun 1930-an, kemudian terulang lagi pada tahun 1982 ketika negara-negara Amerika Latin dan beberapa NSB lainnya mengalami kesulitan serius dalam mengelola hutang luar negerinya. Meskipun terdapat kontroversi apakah krisis ini dapat disebut sebagai collective debt problem of the world, tetapi dunia mengakui bahwa saat itu problema hutang luar negeri NSB berada pada posisi serius. ${ }^{8}$ Terbukti kemudian hutang luar negeri NSB ini telah meningkat dari sekitar 755 milyar \$ pada tahun 1981 menjadi 1.245 milyar \$ pada akhir $1988 .^{9}$ Hal ini menunjukkan bahwa meskipun dalam masa krisis hutang luar negeri banyak terjadi debt relief dan debt reschedulling, namun dalam periode selanjutnya volume hutang luar negeri ini justru meningkat pesat. Peningkatan ini sebagian berasal dari penambahan hutang luar negeri dalam rangka mengatasi krisis, dan sebagian lain merupakan kebutuhan rutin pembiayaan negara-negara lain terutama di Asia.

Sebagaimana diketahui, salah satu upaya menyelesaikan krisis hutang 1980an dilakukan melalui Baker Plan 1985 yang antara lain justru meningkatkan volume hutang dari negara-negara Amerika Latin, sedangkan dalam Brady Plan dilakukan pemutihan sebagian hutang negara-negara

Terdapat banyak literatur yang mengkaji bunga/riba, baik secara normatif maupun secara economic-rationale. Lihat mislanya: Basyir, A. Azhar (1983), Riba, Hutang-Piutang dan Gadai, Yogyakarta, PT Almaarif, Abod, Sheikh Ghazali Sheikh (Et al) (1992), Islamic Finance, Kuala Lumpur, Quill Publisher, Siddiqi, M. Nejatullah (1991), Bank Tanpa Bunga, Bandung, PT Pustaka.

${ }^{8}$ Terdapat argumentasi yang mengatakan bahwa krisis itu hanya merupakan fenomena regional, yaitu di beberapa Negara Amerika Latin, sedangkan di negara-negara lain, misalnya di Asia, tidak terjadi krisis yang serupa. Lihat misalnya, Sachs, Jeffrey. (1990), "Making The Brady Plan Work", International Economics and International Economic Policy: a Reader, Philip King (ed),Singapore, McGraw-Hill Publishing Company, hal 331.

'World Bank (1989), World Debt Tables 1988.

${ }^{10}$ Corbridge, Stuart (1993), Debt and Development, Blackwell, Oxford U.K. dan Cambridge U.S.A. 
Afrika oleh Jepang. ${ }^{10}$ Langkah ini memberikan indikasi bahwa dalam beberapa waktu mendatang NSB masih tetap akan tergantung dengan hutang luar negeri dan potensi terulangnya krisis, sebagaimana tahun 1980-an, akan dimungkinkan.

- Hutang luar negeri negara-negara Islam sangat bervariasi, bahkan sebagian diantaranya tidak memiliki hutang luar negeri (bahkan menjadi kreditur). Beberapa negara di Timur Tengah (Arab Saudi, Kuwait, Uni Emirat Arab) tidak memiliki hutang luar negeri, sementara di antara yang lain dapat diklasifikasikan sebagai pengutang kecil atau tengah (misalnya Chad, Sieera Lone, Kamerun, Jordan, Tunisia, Libanon), sementara lainnya termasuk pengutang besar (misalnya Indonesia, Malaysia, Mesir, Maroko, Republik Arab Siria). Dalam situasi krisis ekonomi saat ini dapat diduga beberapa negara lslam juga mengalami peningkatan jumlah hutang luar negerinya. Pada saat ini hutang luar negeri Indonesia diperkirakan mencapai 135 milyar \$. Data-data mengenai hutang luar negeri dalam realitasnya masih dapat berkembang, mengingat berbagai hutang untuk kepentingan militer kebanyakan tidak dilaporkan kepada publik. Untuk negaranegara yang memiliki proyek pengembangan militer/senjata yang besar -misalnya Irak, Pakistan, Lybia - diduga jumlah ini cukup siknifikan.

Selain secara nominal jumlahnya cukup besar, hutang luar negeri negaranegara Islam juga mengalami perkembangan yang amat pesat. Secara rata-rata dibandingkan dengan tahun 1980 hingga 1987 hutang luar negeri telah meningkat hingga $47 \%$, sementara untuk periode yang sama rata-rata seluruh nsb hanya meningkat $43 \%$. Peningkatan volume hutang luar negeri ini tentu saja meningkatkan beban pembayaran kembali, bahkan beberapa diantara negara-negara ini memiliki beban yang secara ekonomi 'sangat berbahaya'. Pada tahun 1995, rasio total hutang luar negeri dengan GNP negara-negara seperti Sierra Lone, Guinea Bassau, Mali, Republik Yaman, Mauritania, Kamerun, Rep. Arab Syria, Jordan dan Gabon mencapai lebih dari $100 \%$. Hal ini berarti output nasional selama satu tahun tidak cukup untuk melunasi keseluruhan hutang luar negerinya.

Sementara itu rasio total hutang luar negeri dengan ekspor barang dan jasa pada tahun 1980 rata-rata di atas $200 \%$ dan meningkat cukup drastis pada tahun 1995. Ambang batas toleransi kemampuan pembayaran hutang luar negeri suatu negara juga dapat dilihat dari debt service ratio (DSR), yaitu perbandingan antara pembayaran pokok dan bunga hutang dengan ekspor barang dan jasa. DSR beberapa negara jauh di atas $30 \%$, misalnya Sierra Lone, Guinea Biseau, Pakistan, Indonesia, dan Maroko

Dari berbagai indikator di atas dapat disimpulkan bahwa beban hutang luar negeri negara-negara Islam cukup besar, bahkan berada di ambang batas kemampuan ekonomi. Memang, selama ini krisis hutang dunia tidak bersumber dari negara-negara Islam, akan tetapi negaranegara ini punya prediksi buram tentang hutang di masa depan. Beberapa negara yang memiliki DSR tinggi tentunya berpotensi untuk terjerat krisis hutang.

Selama ini kritis hutang dunia memang hanya merujuk pada kasus-kasus di Amerika Latin, dimana tidak terdapat negara Islam. Hingga beberapa saat sebelum krisis ekonomi melanda negaranegara di Asia (khususnya), potret paradoksal hutang luar negeri sering dirujukkan kepada negara-negara pengutang di Asia (Asia Timur). Jika tahun 1980-an sering disebut sebagai the lost decade bagi Amerika Latin, maka negara-negara 
pengutang Asia Timur justru menunjukkan kinerja ekonomi yang mengagumkan. Bahkan, beberapa studi telah menyimpulkan bahwa negara-negara pengutang Asia Timur, misalnya Indonesia, tidak akan terjerembab ke dalam krisis hutang luar negeri sebagaimana Amerika Latin". Namun demikian, kesimpulan ini nampaknya harus direvisi sehubungan dengan beberapa fakta yang terjadi akhir-akhir ini.
Memang benar bahwa krisis ekonomi yang melanda negara-negara Asia saat ini bukan diawali oleh krisis hutang luar negeri, namun struktur pembiayaan yang ditopang dengan hutang ini ternyata telah memperparah krisis. Hutang luar negeri ternyata menghasilkan pertumbuhan ekonomi semu yang sempat dikagumi dalam waktu-waktu sebelumnya.

"Kaminsky, L Graciela dan Alfredo Preiera (1996), "The Debt Crisis: Lessons of the 1980s for the 1990s", Joumal of Development Economics, Vol 50. Untuk kasus Indonesia lihat Radelet, Steven (1995), "Indonesian Foreign Debt: Head for a Crisis or Financing Sustainable Growth?", Bulletin of Indonesian Economic Studies, Vol 31, No 3, Desember. 
Topik: Perspektif Islam tentang Utang Luar Negeri..., MB Hendrie Anto

Tabel 1

Indikator Utang Luar Negeri Negara-negara Islam (1980 1995)

\begin{tabular}{|c|c|c|c|c|c|c|}
\hline \multirow[t]{2}{*}{ NAMA NEGARA } & \multirow{2}{*}{\multicolumn{2}{|c|}{$\begin{array}{l}\text { Total External Debt } \\
\text { (million } \$)\end{array}$}} & \multicolumn{4}{|c|}{ External Debt as percentage of } \\
\hline & & & \multicolumn{2}{|c|}{ GNP } & \multicolumn{2}{|c|}{$\begin{array}{c}\text { Export of Goods and } \\
\text { Services }\end{array}$} \\
\hline & 1980 & 1995 & 1980 & 1995 & 1980 & 1995 \\
\hline \multicolumn{7}{|c|}{ Low income economies } \\
\hline $\begin{array}{l}\text { Chad } \\
\text { Siearra Leone } \\
\text { Niger } \\
\text { Burkina Faso } \\
\text { Bangladesh } \\
\text { Uganda } \\
\text { Guiena Bissau } \\
\text { Mali } \\
\text { Yemen Rep. } \\
\text { Gambia, The } \\
\text { Benin } \\
\text { Pakistan } \\
\text { Mauritania } \\
\text { Guinea } \\
\text { Senegal } \\
\text { Cameroon }\end{array}$ & $\begin{array}{r}285 \\
435 \\
863 \\
330 \\
4.230 \\
689 \\
145 \\
732 \\
1.684 \\
137 \\
424 \\
9.930 \\
843 \\
1.134 \\
1.473 \\
2.588\end{array}$ & $\begin{array}{r}908 \\
1.226 \\
1.633 \\
1.267 \\
16.370 \\
3.564 \\
894 \\
3.066 \\
6.212 \\
426 \\
1.646 \\
30.152 \\
2.467 \\
3.242 \\
3.845 \\
9.350\end{array}$ & $\begin{array}{r}39.5 \\
38.3 \\
34.5 \\
19.5 \\
32.6 \\
54.6 \\
137.8 \\
45.4 \\
\\
61.5 \\
30.2 \\
42.4 \\
125.5 \\
\\
50.5 \\
37.9\end{array}$ & $\begin{array}{r}81.4 \\
159.7 \\
91.2 \\
55.0 \\
56.3 \\
63.7 \\
353.7 \\
131.9 \\
155.2 \\
\\
81.8 \\
49.5 \\
243.3 \\
91.2 \\
82.3 \\
124.4\end{array}$ & $\begin{array}{r}399.6 \\
157.7 \\
132.8 \\
88.0 \\
360.4 \\
208.1 \\
\\
227.3 \\
\\
206.6 \\
133.1 \\
208.7 \\
306.1 \\
\\
162.7 \\
140.7\end{array}$ & $\begin{array}{r}339.0 \\
1.163 .5 \\
571.7 \\
346.1 \\
298.2 \\
555.1 \\
1.874 .3 \\
467.1 \\
192.1 \\
235.1 \\
285.6 \\
257.9 \\
458.5 \\
453.4 \\
274.3 \\
338.3\end{array}$ \\
\hline \multicolumn{7}{|c|}{$\begin{array}{l}\text { Middle income economies } \\
\text { Lower middle income }\end{array}$} \\
\hline $\begin{array}{l}\text { Egypt, Arab Rep } \\
\text { Indonesia } \\
\text { Marroco } \\
\text { Syrian Arab Rep } \\
\text { Jordan } \\
\text { Tunisia } \\
\text { Lebanon } \\
\text { Turkey }\end{array}$ & $\begin{array}{r}19.131 \\
20.938 \\
9.247 \\
3.552 \\
1.971 \\
3.527 \\
510 \\
19.131\end{array}$ & $\begin{array}{r}34.116 \\
107.831 \\
22.147 \\
21.318 \\
7.944 \\
9.938 \\
2.966 \\
73.592\end{array}$ & $\begin{array}{l}89.2 \\
28.0 \\
50.7 \\
27.2 \\
41.6 \\
\\
27.4\end{array}$ & $\begin{array}{r}73.3 \\
56.9 \\
71.0 \\
134.8 \\
126.2 \\
57.3 \\
25.5 \\
44.1\end{array}$ & \begin{tabular}{r|}
207.7 \\
\\
213.9 \\
106.3 \\
129.9 \\
96.0 \\
\\
333.1
\end{tabular} & $\begin{array}{l}208.1 \\
202.9 \\
200.9 \\
336.8 \\
163.8 \\
113.2 \\
152.7 \\
177.8\end{array}$ \\
\hline \multicolumn{7}{|c|}{ Upper middle income countries } \\
\hline $\begin{array}{l}\text { Gabon } \\
\text { Malaysia } \\
\text { Oman } \\
\text { Saudi Arabia }\end{array}$ & $\begin{array}{r}1.514 \\
6.611 \\
599\end{array}$ & $\begin{array}{r}4.492 \\
34.352 \\
3.107\end{array}$ & $\begin{array}{l}39.2 \\
28.0 \\
11.2\end{array}$ & $\begin{array}{r}121.6 \\
42.6 \\
29.5\end{array}$ & $\begin{array}{l}62.2 \\
44.6 \\
15.4\end{array}$ & $\begin{array}{r}160.3 \\
40.8 \\
48.2\end{array}$ \\
\hline \multicolumn{7}{|c|}{ High income economies } \\
\hline $\begin{array}{l}\text { Kuwait } \\
\text { Uni Arab Emirates }\end{array}$ & & & . & & & \\
\hline
\end{tabular}


Topik: Perspektif Islam tentang Utang Luar Negeri..., MB Hendrie Anto

\begin{tabular}{|c|c|c|c|c|c|}
\hline \multirow[t]{2}{*}{ NAMA NEGARA } & \multicolumn{2}{|c|}{$\begin{array}{l}\text { Debt Service } \\
\text { As \% of export of } \\
\text { goods \& services }\end{array}$} & $\begin{array}{l}\text { Multilateral debt as } \\
\% \text { of total external } \\
\text { debt }\end{array}$ & \multirow[b]{2}{*}{1980} & \multirow[b]{2}{*}{1995} \\
\hline & 1980 & 1995 & & & \\
\hline \multicolumn{6}{|c|}{ Low income economies } \\
\hline $\begin{array}{l}\text { Chad } \\
\text { Siearra Leone } \\
\text { Niger } \\
\text { Burkina Faso } \\
\text { Bangladesh } \\
\text { Uganda } \\
\text { Guiena Bissau } \\
\text { Mali } \\
\text { Yemen Rep. } \\
\text { Gambia, The } \\
\text { Benin } \\
\text { Pakistan } \\
\text { Mauritania } \\
\text { Guinea } \\
\text { Senegal } \\
\text { Cameroon }\end{array}$ & $\begin{array}{r}8.4 \\
23.2 \\
21.7 \\
5.9 \\
23.7 \\
17.3 \\
5.4 \\
\\
6.2 \\
6.3 \\
18.3 \\
17.3 \\
28.7 \\
15.2\end{array}$ & $\begin{array}{r}5.9 \\
60.3 \\
19.8 \\
11.1 \\
13.3 \\
21.3 \\
66.9 \\
12.6 \\
3.2 \\
14.0 \\
8.4 \\
35.3 \\
21.5 \\
25.3 \\
18.7 \\
20.1\end{array}$ & - & $\begin{array}{l}26.1 \\
14.2 \\
16.5 \\
42.8 \\
30.2 \\
11.5 \\
20.1 \\
23.7 \\
14.9 \\
29.9 \\
24.5 \\
15.4 \\
11.5 \\
11.5 \\
17.8 \\
16.7\end{array}$ & $\begin{array}{l}73.0 \\
34.3 \\
53.2 \\
77.6 \\
59.7 \\
61.8 \\
56.1 \\
45.2 \\
20.6 \\
76.0 \\
52.3 \\
40.5 \\
36.8 \\
45.2 \\
48.4 \\
17.9\end{array}$ \\
\hline \multicolumn{6}{|c|}{ Middle income economiesLower middle income } \\
\hline $\begin{array}{l}\text { Egypt, Arab Rep } \\
\text { Indonesia } \\
\text { Marroco } \\
\text { Syrian Arab Rep } \\
\text { Jordan } \\
\text { Tunisia } \\
\text { Lebanon } \\
\text { Turkey }\end{array}$ & $\begin{array}{r}13.4 \\
33.4 \\
11.4 \\
8.4 \\
14.8 \\
28.0\end{array}$ & $\begin{array}{r}14.6 \\
30.9 \\
32.1 \\
4.6 \\
17.9 \\
17.0 \\
13.1 \\
27.7\end{array}$ & & $\begin{array}{r}13.7 \\
8.8 \\
7.8 \\
8.8 \\
8.0 \\
12.3 \\
15.2 \\
11.2\end{array}$ & $\begin{array}{r}12.4 \\
18.6 \\
30.8 \\
4.8 \\
14.9 \\
37.2 \\
6.7 \\
12.2\end{array}$ \\
\hline \multicolumn{6}{|c|}{ Upper middle income countries } \\
\hline $\begin{array}{l}\text { Gabon } \\
\text { Malaysia } \\
\text { Oman } \\
\text { Saudi Arabia }\end{array}$ & $\begin{array}{r}17.7 \\
6.3 \\
6.4\end{array}$ & $\begin{array}{r}15.8 \\
7.8 \\
7.5\end{array}$ & & $\begin{array}{r}2.7 \\
11.3 \\
5.8\end{array}$ & $\begin{array}{r}14.8 \\
4.8 \\
5.7\end{array}$ \\
\hline \multicolumn{6}{|c|}{ High income economies } \\
\hline $\begin{array}{l}\text { Kuwait } \\
\text { Uni Arab Emirates }\end{array}$ & & & - & & \\
\hline
\end{tabular}

Sumber : World Bank (1997) 
Dengan demikian, bagi negara-neara Islam di Asia krisis hutang sebagaimana yang terjadi di Amerika Latin nampaknya telah berada di depan mata. Fakta ini tentunya akan menjadi pengalaman yang berharga bagi negara-negara Islam pengutang di wilayah lainnya.

\section{Penyebab Meningkatnya Hutang Luar Negeri \\ Meningkatnya beban hutang luar negeri} ini disebabkan oleh berbagai faktor yang kompleks, namun secara garis besar berasal dari faktor internal dan eksternal. Terdapat beberapa berbedaan pendapat di kalangan ekonom tentang faktor mana yang lebih dominan.
Beberapa faktor internal ini misalnya :

(1) Tingkat konsumsi yang berlebihan dan meningkatnya defisit anggaran yang disebabkan oleh beberapa hal, misalnya: meningkatnya impor, meningkatnya beban pembayaran hutang luar negeri dan capital outflow. Meningkatnya budged defisit juga disebabkan oleh strategi pembangunan yang terlalu mengejar pertumbuhan, sehingga banyak membutuhkan outsource financing. ${ }^{12}$

(2) Beberapa negara Islam harus mengeluarkan dana besar untuk menunjang operasi perusahaan milik negara (State Owner Enterprises/ BUMN) yang dikarenakan oleh keputusan yang buruk dalam investasi, pricing, manajemen perusahaan dan program investasi yang overambious. ${ }^{13}$

Tabel 2

Transfer Bersih Rata-rata/tahun dari Pemerintah kepada BUMN Non Keuangan

\begin{tabular}{|l|c|c|}
\hline Persentase dari GDP & $1978-82$ & $1983-85$ \\
\hline Mesir & 5,2 & 3.5 \\
Marroko & 2.1 & 1.0 \\
Turki & 3.0 & 1.5 \\
\hline
\end{tabular}

Sumber: World Development Report (1988), sebagaimana dikutip E Freiyer (1992)

${ }^{12}$ Freyer, Erich (1992), ibid, hal 183.

${ }^{13}$ Freyer, Erich (1992), ibid, hal 184. 
(3) Beberapa negara memiliki pengeluaran untuk militer sangat besar, misalnya beberapa negara Arab, Asia dan Afrika (Lybia, Irak, Pakistan, Iran, Afganistan, dan lain-lain)

(4) Pengelolaan ekonomi yang buruk, terutama pengelolaan hutang, sehingga kinerja ekonomi (inflasi, nilai tukar, transaksi berjalan, dan lain-lain) juga buruk. Dalam keadaan inflasi tinggi, overvalue exchange rates, negatif riel interest rate, dan meningkatnya defisit transaksi berjalan, maka external debt seringkali menjadi alternatif financing tidak bisa terhindarkan.

\section{Bebarapa faktor eksternal misalnya:}

(1) Rendahnya term of trade barang-barang ekspor negara Islam di pasaran dunia, sehingga menurunkan penerimaan ekspor. Di sisi lain biaya-biaya impor meningkat, terutama disebabkan oleh menguatnya dollar terhadap beberapa mata uang negara berkembang.

(2) Memburuknya perekonomian negaranegara OECD sehingga melakukan berbagai proteksi untuk melindungi dari ekspansi ekspor negara-negara berkembang, termasuk negara-negara Islam. ${ }^{14}$

(3) Menurunnya penerimaan dari beberapa sektor andalan, misalnya uang kiriman (remitance) dari tenaga kerja di luar negeri dari negara-negara Pakistan, Yaman, Sudan, Turki, dan Maroko. Remitance merupakan salah satu sumber penerimaan negara yang diandalkan oleh negara-negara ini

(4) Menaiknya suku bunga riil sehingga menyebabkan beban hutang luar negeri meningkat drastis. Berbagai studi telah menyimpulkan bahwa tingkat bunga merupakan faktor yang amat penting dalam menentukan kemampuan pembayaran hutang dan terjadinya resiko- resiko default. ${ }^{15}$ Kenaikan suku bunga riil ini menyebabkan negara-negara debitur melakukan pengeluaran tambahan dalam pembayaran hutang sebesar US\$ 41 miliar pada tahun 1981-1982.

Beban hutang luar negeri ini telah menimbulkan banyak dampak, baik negatif maupun positif. Dampak ini misalnya: (1) menurunnya/melambatnya tingkat pertumbuhan ekonomi, (2) meningkatnya pengangguran, (3) menurunnya investasi, (4) meningkatnya problematik lingkungan, kesehatan, moral, dan lain-lain. ${ }^{16}$

\section{Alternatif Mengatasi Hutang Luar Negeri}

Sebagaimana telah dikemukakan di atas, bahwa hutang luar negeri merupakan masalah yang kompleks, sehingga tidak mudah untuk menemukan solusi yang jitu. Demikian kompleks dan bervariasinya hutang luar negeri negara-negara Islam,

${ }^{14} \mathrm{Krueger}$, Anne dan Sebastian Erward (1989), Resolving the Debt Crisis and Restoring Developing Countries'Credithworthiness: Policy Reform and the Resolution of the Debt Crisis : A Comment, Camegie-Rechester Conference Series on Public Policy (CCS), Vol 30, Spring.

${ }^{15}$ Derminic-Kurt, Asli dan Enricha Detragiache (1994), Interest Rate, "Official Lending and The Debt Crisis: A Reassesment", Joumal of Development Economics, Vol 44, No 2, Agustus. Lihat pula Cline, William (1984), Intemational Debt: Systemic Risk and Policy Response, Washington DC, Institue for International Economics.

${ }^{16}$ Freyer, Erich (1992), "The Debt Crisis : International Financial Institution and Islamic Countries", Intemational Economic Relation from Islamic Perspectives, Mannan, M.A (Ed), Jeddah Saudi Arabia, IRTI and IDB, hal 180. 
maka tentunya tidak ada satu obat mujarab (panaceae) yang dapat menyembuhkan penyakit di semua negara Islam. Beberapa langkah berikut ini kiranya dapat menjadi pertimbangan secara umum, sedangkan implementasinya disesuaikan dengan situasi dan kondisi masing-masing negara.

- Memperbaiki kinerja ekonomi

Perbaikan kinerja ekonomi tentu merupakan syarat dasar yang utama, sebab dengan membaiknya kinerja ekonomi maka kemampuan tumbuh dan berkembang mandiri akan meningkat. Selain itu konsekuensi negatif dari memburuknya kinerja ekonomi dapat dikurangi.

- Mobilisasi sumber pembiayaan dalam negeri

Sumber pembiayaan dalam negeri beberapa negara Islam, Indonesia misalnya, belum dimobilir dengan optimal. Banyak negara Islam yang terpaku dalam satu model mobilisasi konvensional yang sempit, padahal Islam memiliki alternatif-alternatif pembiayaan yang potensial. Zakat, Jizyah, Kharaj, serta berbagai pajak dan bea merupakan sumber-sumber pembiayaan pembangunan yang potensial.

- Bagi negara-negara highly-indebtedness, seperti Indonesia dan Malaysia, perlu menggalang kerjasama dengan negara-negara pengutang lain untuk meminta suatu debt relief. Selain itu sebagai langkah pelengkap, perlu diupayakan suatu konversi dari debt creating flow menjadi non debt creating flow-sehingga dampak negatif hutang luar negeri dapat terkurangi.

- Negara-negara Islam yang kaya wajib. membantu negara-negara Islam miskin, sebagaimana ajaran Islam yang mewajibkan orang kaya menolong fakir miskin. Bantuan ini dapat berwujud hibah (grant/al qadhul hasan) atau soft and very soft loans, sehingga benarbenar bermisi menolong.

- Meningkatkan kerjasama ekonomi di antara negara-negara Islam

Terdapat alasan-alasan normatif dan positif yang mendorong ditingkatkannya kerjasama di antara negara-negara Islam. Hingga saat ini kerjasama ekonomi diantara negara-negara Islam belum optimal, sekalipun secara formal telah dibentuk institusi-institusi dan skema kerjasama. Secara normatif ajaran Islam menganjurkan adanya kerjasama dan tolong menolong dalam pembangunan (kebajikan), sebagaimana disampaikan dalam Al-Qur'an dan Hadist. Selain itu dalam teori-teori ekonomi intenasional telah dibahas berbagai keuntungan kerjasama ekonomi. Dalam fakta, kondisi masingmasing negara Islam sangat bervariasi, di mana di satu pihak berlimpah sumber daya di pihak lain sangat kekurangan. Kerjasama ini antara lain meliputi:

\section{- Kerjasama Finansial}

Beberapa negara Islam sangat kaya akan potensi finansial, misainya negara-negara petrodollar. Danadana ini dapat digunakan sebagai alternatif pengganti hutang luar negeri kepada negara-negara maju, dimana mekanismenya tentu disesuaikan dengan ketentuan syariat. Beberapa produk finansial yang telah diterapkan IDB, seperti Mudarabah, Musharaka (Equity participation), Murabahah (cost plus), Bay Muajjal (Deffered payment), Bay al salam (forward transaction) dan leasing, dapat. 
dikembangkan bagi kerjasama finansial lebih luas. ${ }^{17}$ Aliran danadana dari negara-negara Islam selama ini masih sangat terbatas. Bahkan, banyak dana dari beberapa negara petrodollar mengalir ke negara-negara industri (Barat), dan kemudian digunakan untuk membiayai pinjaman kepada negara-negara berkembang ${ }^{18}$

- Kerjasama ekonomi dan perdagangan

Beberapa studi, baik teoritik maupun empiris telah dilakukan untuk memperkirakan dampak ekonomi dari adanya kerjasama di antara negara-negara Islam. Secara umum diperoleh kesimpulan bahwa adanya kerjasama ini akan memberikan banyak manfaat ekonomi bagi negaranegara Islam. Bahkan, diusulkan adanya suatu pasar bersama di antara negara-negara Islam (/slamic Common Market). ${ }^{19}$ Saat ini telah ada blok-biok perdagangan atau kerjasama ekonomi di antara negara-negara Islam, tetapi transaksi ekonomi-bisnisnya relatif tidak signifikan. ${ }^{20}$ Sebagaimana nampak dalam tabel 3 dan tabel 4 terlihat bahwa transaksi perdagangan di antara negara-negara Islam secara rata-rata kurang dari 4 persen, dan cenderung tidak meningkat berarti dari waktu-ke waktu. Rendahnya kerjasama perdagangan ini tentu saja harus menjadi perhatian, mengingat sebenarnya terdapat potensi ekspor dan impor yang memadai di antara berbagai negara Islam ini.
"Mengenai, S.A. (1992), "International Development Banking in An Islamic Framework: Lessons of Islamic Development Bank Experience", Intemational Economic Relation from Islamic Perspectives, lbid, Hal 155-156.

${ }^{18}(1998)$, Jerat MF, Bandung, Mizan.

${ }^{19}$ Beberapa studi, meskipun dengan data terbaru tahun 1985, telah dilakukan oleh beberapa ekonom. Lihat misalnya: Sadeq, Muhammad AbulHasan (1990), Economic Development in Islam, Malaysia, Pelanduk Publications, serta Chudhury, Masudul Alam (1993), Theory and Practice of Islamic Development Cooperation, Ankara, Stastical, Economic and Social Research and Training Centre for Islamic Countries, Organisation of Islamic Conference.

${ }^{20}$ Beberapa blok perdagangan yang saat ini ada antara lain: (1) Gulf Country Council (GCC) dengan anggota: Bahrain, Kuwait, Oman, Qatar, Saudi Arabia, Uni Emiat Arab, (2) D-8 dengan anggota: Bangladesh, Mesir, Indonesia, Iran, Malaysia, Nigeria, Pakistan, dan Turki, (3) dengan anggota: Economic Cooperation Organization (ECO) dengan anggota: Afganistan, Azerbeijan, Iran, Kazakhstan, Kyrgyzia, Pakistan, Tajikistan, Turky, Turkmenia, Usbekistan 
Topik: Perspektif Islam tentang Utang Luar Negeri..., MB Hendrie Anto

Tabel 3

Ekspor Negara Islam ke Negara Islam dan Masyarakat Eropa 1985

(\% ekspor total)

\begin{tabular}{|lrr|}
\hline NAMA NEGARA & OIC & EC \\
\hline Chad & 4.3 & 35.3 \\
Siearra Leone & 0.2 & 60.2 \\
Niger & 14.1 & 77.1 \\
Burkina Faso & 7.1 & 57.9 \\
Bangladesh & 27.4 & 17.4 \\
Uganda & 2.0 & 50.8 \\
Guiena Bissau & 0.9 & 70.9 \\
Mali & 8.8 & 72.7 \\
Yemen Rep. & 22.2 & 18.0 \\
Gambia, The & 9.5 & 19.6 \\
Benin & 3.4 & 92.4 \\
Pakistan & 24.8 & 22.2 \\
Mauritania & 0.5 & 71.8 \\
Guinea & 10.6 & 66.5 \\
Senegal & 15.4 & 43.0 \\
Cameroon & 2.0 & 76.0 \\
Egypt, Arab Rep & 5.7 & 43.9 \\
Indonesia & 2.8 & 6.2 \\
Marroco & 13.2 & 52.0 \\
Syrian Arab Rep & 8.9 & 55.5 \\
Jordan & 52.4 & 4.4 \\
Tunisia & 9.7 & 69.8 \\
Lebanon & 54.0 & 10.6 \\
Turkey & 2.0 & 40.2 \\
Gabon & 2.6 & 52.2 \\
Malaysia & 4.0 & 14.4 \\
Oman & 1.0 & 3.1 \\
Saudi Arabia & 13.5 & 21.7 \\
Kuwait & 16.3 & 3.5 \\
Uni Arab Emirates & 8.2 & 8.0 \\
\hline
\end{tabular}

Sumber: Choudhury (1993)

Tabel 4

Persentase Perdagangan Intra Blok Perdagangan Negara-negara Muslim (persentase dari perdagangan total)

\begin{tabular}{|clll|}
\hline Blok & & & \\
Perdagangan & 1993 & 1994 & 1995 \\
ECO & 2.5 & 5 & 4.1 \\
D-8 & 3.4 & 3.7 & 3.7 \\
GCC & 7.3 & 6.5 & 5.5 \\
\hline
\end{tabular}


Topik: Perspektif Islam tentang Utang Luar Negeri..., MB Hendrie Anto

\section{Simpulan}

Dari uraian di muka maka dapat ditarik simpulan sebagai berikut:

(1) Manfaat hutang luar negeri bagi pembangunan ekonomi masih diperdebatkan, baik dalam tataran dalam teoritik maupun faktual. Beberapa hasil studi empiris tentang hal ini menunjukkan hasil yang berbeda-beda.

(2) Dalam perspektif Islam terdapat dua pandangan mengenai hutang luar negeri sebagai sumber penutup budged deficit, pandangan pertama memperbolehkan hutang luar negeri sepanjang bentuk dan mekanismenya disesuaikan dengan syariat Islam. Dalam hal ini external financing merupakan implementasi berbagai bentuk kerjasama usaha. Pandangan kedua tidak memperkenankan negara Islam menarik hutang luar negeri, sebab pasti akan berinteraksi dengan sistem bunga. Dalam pandangan Islam, bunga merupakan riba yang dilarang tegas. Dengan demikian, pandangan ini sebenarnya merupakan upaya prefentif agar negara Islam tidak terjerembab dalam transaksi riba.

(3) Struktur hutang luar negeri negaranegara Islam bervariasi satu sama lain, di mana terdapat negara pengutang ringan, tengah dan berat. Bahkan, beberapa negara Islam tidak memiliki hutang luar negeri dan menjadi kreditur. Penyebab tingginya beban hutang luar negeri secara,garis besar dikelompokkan menjadi penyebab internal dan penyebab eksternal.

(4) Beberapa alternatif pemecahan masalah hutang luar negeri antara lain (1) perbaikan kinerja ekonomi, (2) Optimalisasi sumber dana dalam negeri (3) Konversi hutang menjadi penyertaan modal-yang lebih sesuai dengan
Syariah, (3) pengajuan debt relief bagi highly indebtedness country (5) Bantuan negara Islam kaya kepada negara Islam miskin. (4) meningkatkan kerjasama ekonomi di antara negaranegara Islam

(5) Terdapat urgensi dan potensi ekonomi yang besar dari negara-negara Islam untuk menjalin suatu kerjasana ekonomi dalam bidang finansial'dan kerjasama ekonomi-perdagangan.

\section{Daftar Pustaka}

Abod, Sheikh Ghazali Sheikh (Et al) (1992), Islamic Finance, Kuala Lumpur, Quill Publisher.

Basyir, A Azhar (1983), Riba, HutangPiutang dan Gadai, Yogyakarta, PT Almaarif,

Corbridge, Stuart (1993), Debt and Development, Blackwell, Oxford dan Cambridge U.S.A.

Chudhury, Masudul Alam (1993), Theory and Practice of Islamic Development Cooperation, Ankara, Stastical, Economic and Social Research and Training Centre for Islamic Countries, Organisation of Islamic Conference.

Chowdurry, Khorshed dan Amnon Levy. (1997), "Hutang Eksternal dan Implikasinya terhadap Pertumbuhan Ekonomi", Jurnal Ekonomi Pembangunan, Yogyakarta, Fakultas Ekonomi UIl, Volume 2 Nomor 2 hal 337.

Cline, William (1984), International Debt: Systemic Risk and Policy Response, Washington $\mathrm{DC}$, Institue for International Economics.

Derminic-Kurt, Asli dan Enricha Detragiache (1994), Interest Rate, "Official Lend- 
ing and The Debt Crisis: A Reassesment", Journal of Development Economics, Vol 44, No. 2, Agustus.

Freyer, Erich (1992), "The Debt Crisis: International Financial Institution and Islamic Countries", International Economic Relation from Islamic Perspectives, Mannan, M.A (Ed), Jeddah Saudi Arabia, IRTI and IDB, hal 180.

Haque, M Badhul, and Charles Waternberg (1992) "Direct Effect of Debt Overhang and IMF Program", Review of Financial Economics, Spring. sebagaimana dikutip oleh Toni Prasetiantono. (1996), "Hutang Luar Negeri Dan Defisit Transaksi Berjalan", Kelola, Yogyakarta, Magister Manajemen Universitas Gadjah Mada, No 12N.

Ingam, James C. (1986), International Economics, New York, John Wiley \& Sons.

Kaminsky, L Graciela dan Alfredo Preiera (1996), "The Debt Crisis: Lessons of the 1980s for the 1990s", Journal of Development Economics, Vol 50.

Krueger, Anne dan Sebastian Erward (1989), "Resolving the Debt Crisis and Restoring Developing Countries'Credithworthiness: Policy Reform and the Resolution of the Debt Crisis: A Comment", CarnegieRechester Conference Series on Public Policy (CCS), Vol 30, Spring.
Mannan, Abdul (1992), Teori dan Praktek Ekonomi Islam, Yogyakarta, PT Dana Bhakti Wakaf, hal 237-238.

Meenai, S.A. (1992), "International Development Banking in An Islamic Framework: Lessons of Islamic Development Bank Experience", International Economic Relation from Islamic Perspectives, Ibid, Hal 155156.

Razzaq, Abdur (1998), Jerat Hutang IMF, Bandung, Mizan Pustaka.

Radelet, Steven (1995), "Indonesian Foreign Debt: Head for a Crisis or Financing Sustainable Growth?", Bulletin of Indonesian Economic Studies, Vol 31, No 3, Desember.

Sadeq, Muhammad Abul Hasan (1990), Economic Development in Islam, Malaysia, Pelanduk Publications.

Siddiqi, M Nejatullah (1991), Bank Tanpa Bunga, Bandung, PT Pustaka.

Sachs, Jeffrey. (1990), "Making The Brady Plan Work", International Economics and International Economic Policy. a Reader, Philip King (ed), Singapore, McGraw-Hill Publishing Company, hal. 331.

Todaro, Michel P. (1994), Economic Development, $5^{\text {th }}$ Edition, New York, Longman Publishing.

World Bank (1989), World Debt Tables 1988.

World Bank (1997), World Development Report 1997. 